\title{
Efficacy of pulmonary rehabilitation on patients with non-cystic bronchiectasis according to disease severity
}

\author{
Sami DENiZ ${ }^{1}$ (ID) \\ Hülya ŞAHIN $^{1}$ (ID) \\ Ahmet Emin \\ ERBAYCU $^{2}($ ID $)$
}

\author{
${ }^{1}$ Clinic of Chest Diseases, Suat Seren Chest Diseases and Thoracic Surgery \\ Research and Training Hospital, İzmir, Turkey \\ 1 Suat Seren Göğüs Hastalıkları ve Gögüs Cerrahisi Ĕgitim Araştırma \\ Hastanesi, Göğüs Hastalıkları Kliniği, İzmir, Türkiye \\ 2 Department of Chest Diseases, İzmir Bakırçay University Faculty of \\ Medicine, İzmir, Turkey \\ ${ }^{2}$ Izmir Bakırçay Üniversitesi Tıp Fakültesi, Göğ̈̈s Hastalıkları Anabilim Dalı, \\ izmir, Türkiye
}

Cite this article as: Deniz S, Şahin H, Erbaycu AE. Efficacy of pulmonary rehabilitation on patients with non-cystic bronchiectasis according to disease severity. Tuberk Toraks 2021;69(4):449-457.

\section{Yazışma Adresi (Address for Correspondence)}

\section{Dr. Ahmet Emin ERBAYCU}

Department of Chest Diseases,

İzmir Bakirçay University Faculty of Medicine, IZMIR - TURKEY

e-mail: afumetsu67@gmail.com

CCopyright 2021 by Tuberculosis and Thorax.

Available on-line at www.tuberktoraks.org.com

\begin{abstract}
Efficacy of pulmonary rehabilitation on patients with non-cystic bronchiectasis according to disease severity

Introduction: The European Respiratory Society guidelines support pulmonary rehabilitation $(P R)$ in bronchiectasis through high-quality evidence. This study aimed to evaluate the efficacy of $P R$ on bronchiectasis patients according to disease severity assessed by the Bronchiectasis Severity Index (BSI).

Materials and Methods: This prospective study included patients with stable bronchiectasis. Demographic data of all patients were questioned. All patients underwent an 8-week PR program. The patients were grouped into three according to disease severity (mild, moderate and severe) based on their BSI scores. The following parameters were evaluated at baseline (pre-PR) and after $P R$ (post-PR): pulmonary function test results, carbon monoxide diffusion capacity, body mass index, exercise capacity (6-minute walking test), quality of life (QoL; St. George's Respiratory Questionnaire), and Hospital Anxiety and Depression scores.

Results: The study included 69 patients ( 55 males; mean age, $62.6 \pm 9$ years). After $P R$, the patients were observed to have significantly improved QoL and exercise capacity $(p<0.05)$. According to BSI, $16(23.2 \%), 29(42.0 \%)$, and $24(34.8 \%)$ patients had mild, moderate, and severe bronchiectasis, respectively. These patient groups significantly differed regarding age, exercise capacity, and QoL $(p<0.05)$. Comparing the change between post- $P R$ and pre-PR values of the study parameters ( $\Delta=$ post- $P R$ value - pre- $P R$ value), no significant differences were observed regarding the exercise capacity and $Q o L(p>$ $0.05)$ in the groups.
\end{abstract}


Conclusion: PR increases exercise capacity and QoL in bronchiectasis patients, and its efficacy does not differ according to disease severity. Thus, appropriate bronchiectasis patients should be referred to PR program regardless of disease severity.

Key words: Bronchiectasis; pulmonary rehabilitation; bronchiectasis severity index

ÖZ

\section{Non-kistik bronşektazide pulmoner rehabilitasyonun hastalık şiddetine göre etkinliği}

Giriş: Avrupa Solunum Derneği kılavuzları bronşektazide pulmoner rehabilitasyonu (PR) yüksek kalitede kanıtla desteklemektedir. Bu çalışma; bronşektazide PR'nin etkinliğini, bronşektazi şiddet indeksi kullanılarak, hastalığın şiddetine göre değerlendirmeyi amaçlamaktadır.

Materyal ve Metod: Bu prospektif çalışma stabil bronşketazili hastaları içermektedir. Tüm hastaların demografik verileri sorgulanmıştır. Tüm hastalar sekiz haftalık PR programına alınmıştır. Indeks kullanılarak hastalığın şiddetine göre hastalar üç gruba ayrılmıştır (hafif, ılımlı ve şiddetli). Başlangıçta (pre-PR) ve PR sonrası (post-PR); pulmoner fonksiyon test sonuçları, karbon monoksid difüzyon kapasitesi, vücut kitle indeksi, egzersiz kapasitesi (6-dakika yürüme testi), yaşam kalitesi (St. George Solunum Ölçeği) ve Hastane Anksiyete Depresyon ö/çeği değerlendirilmiştir.

Bulgular: Çalışmaya 69 hasta (55 erkek; ortalama yaş 62,6 9 yıl) alındı. Pulmoner rehabilitasyon sonrası hastalarda anlamlı şekilde yaşam kalitesi ve egzersiz kapasitesi artışı gözlendi $(p<0,05)$. Bronşektazi şiddet indeksine göre, $16(\% 23,2), 29(\% 42)$ ve 24 (\%34.8) hasta sırasıyla hafif, ılımlı ve şiddetli bronşektaziye sahip idi. Bu hasta grupları yaş, egzersiz kapasitesi ve yaşam kalitesi açısından farklılık gösterdi $(p<0,05)$. Pre- $P R$ ve post-PR çalışma parametrelerindeki değişiklik karşılaştırıldı̆̆ında $(\Delta=p o s t-P R$ değeri - pre-PR değeri), gruplarda egzersiz kapasitesi ve yaşam kalitesi açısından farklııı saptanmadı $(p>0,05)$.

Sonuç: $P R$ bronşektazili hastalarda egzersiz kapasitesi ve yaşam kalitesini artırmaktadır ve etkinliği hastalığın şiddetine göre farklılık göstermemektedir. Böylece, uygun bronşektazi hastaları hastalığın şiddetinden bağımsız olarak PR programına yönlendirilmelidir.

Anahtar kelimeler: Bronşektazi; pulmoner rehabilitasyon; bronşektazi şiddet indeksi

\section{INTRODUCTION}

Bronchiectasis is a chronic respiratory disease characterized by a closed loop of permanent dilatation of the bronchi and frequent bronchial infections, leading to a clinical syndrome of chronic cough and sputum production. Elimination of exacerbations is the key target of therapy (1).

According to the European Respiratory Society (ERS) guidelines, pulmonary rehabilitation (PR) is supported by high-quality evidence. Most therapy recommendations are conditional and based on low to very low quality of evidence (2-4). Patients with bronchiectasis experience reductions in their exercise capacities and quality of life (QoL) (5). The aims of PR in patients with bronchiectasis include improving patients' exercise capacity through certain effects on the patients' aerobic capacity and peripheral muscles, providing disease management, and improving QoL (6).

There are some studies in the literature that investigate the effects of PR on bronchiectasis $(5,6)$. However, to the best of our knowledge, there are no sufficient data comparing the efficacy of PR with regard to the severity of bronchiectasis. Thus, the present study aimed to evaluate the efficacy of PR on patients with bronchiectasis according to disease severity as assessed by the Bronchiectasis Severity Index (BSI).

\section{MATERIALS and METHODS}

\section{Patients}

The present prospective study included patients aged $\geq 18$ years who were diagnosed with stable non-cystic bronchiectasis through high-resolution computed tomography (HRCT) and referred to the PR unit between 2016-2018 in Health Science University, Dr Suat Seren Chest Disease and Thoracic Surgery Research and Training Hospital. Patients were excluded according to the following criteria: presence of acute infections, history of other lung diseases (such as active or inactive pulmonary tuberculosis, lung cancer, interstitial lung diseases, asthma) or comorbidities, being diagnosed with bronchiectasis due to cystic fibrosis, presence of orthopaedic, neurologic or cardiovascular impairment that would prevent patients from doing exercises, being unable or unwilling to complete the PR program, and being not capable of providing informed consent. The study was approved by the local institutional review board (1603-2016-2906). An informed consent was obtained from all patients for their participation in the study. 


\section{Measurements}

All patients were examined by a cardiologist and a physical therapist. Number of hospitalizations and emergency visits in the previous year and demographic and clinical characteristics were questioned for all patients. sputum culture results and, if any, chronic colonization or recurrence of Pseudomonas aeruginosa were examined. The frequency of bronchiectasis was investigated through HRCT.

In the PR unit, body mass index (BMI) values were calculated by measuring height and weight of the patients. Arterial blood samples were analysed. Pulmonary function tests (PFT) were performed by a body plethysmography (Zan 500 Bodyplethysmographie, Germany) and by measuring diffusing capacity of the lungs for carbon monoxide (DLCO; Zan 300, Germany). The percent predicted forced expiratory volume in 1 second $\left(\mathrm{FEV}_{1} \%\right)$, the percent predicted forced vital capacity (FVC\%), and $\mathrm{FEV}_{1} / \mathrm{FVC}$ were recorded. All measurements were performed both before and after PR.

6-minute walking test (6MWT) was performed according to the American Thoracic Society (ATS) guidelines (7). and the distance walked in 6 minutes [6-minute walk distance (6MWD)] was recorded for each patient before and after PR.

Delta 6MWT was accepted as 30 meters, and higher values were considered significant. All patients were evaluated with the Medical Research Council (MRC) dyspnoea scale for assessment of patients' breathlessness (the scale is scored from 1 [best score] to 5 [worstscore]),6St. George's Respiratory Questionnaire (SGRQ) for assessment of QoL (high scores indicates worsened disease and increased symptoms) (8) and Hospital Anxiety Depression Scale (HADS) for the assessment of depression and anxiety (the scale consists of 14 questions; lower scores represents lower levels of anxiety and depression) $(9,10)$. The severity of bronchiectasis in all patients was determined using BSI (3).

BSI was calculated using the following criteria: age, $\mathrm{BMI}$, predicted $\mathrm{FEV}_{1} \%$, hospitalization and emergency visits, MRC score, colonisation status, and frequency of bronchiectasis. Based on the calculated index scores, the patients were categorized into three groups as patients with mild bronchiectasis (a score of 0-4), patients with moderate bronchiectasis (a score of 5-8) and patients with severe bronchiectasis (a score of $>9$ ) (3).

\section{Interventions}

All patients underwent a PR program twice a week during a period of 8 weeks with each session being 2-h long. The exercise program consisted of breathing exercises including pursed lip breathing, diaphragmatic breathing and thoracic expansion exercises, relaxation and stretching exercises, peripheral muscle strength training, upper and lower extremity stretching, and strengthening and aerobic exercises. The patients were trained for nutritional requirements, PR, and the exercise programme. Additionally, bronchial hygiene techniques and dyspnoea-reducing positions were told and the necessary training was given to the patients. All strengthening exercises were started with zero weight exercises and then a half kilogram of weight was added in every four sessions of exercises according to the Borg's scale (4-6). A treadmill and a bicycle/arm ergometer were used for aerobic exercises. The patients were trained at $60-90 \%$ of their maximum heart rates. The Borg dyspnoea scores were used to regulate the exercises (6). Exercise intensities were increased depending on the progress of each patient. During the exercises, the patients were monitored and evaluated using pulse oximetry. Accordingly, in case peripheral arterial oxygen saturation $\left(\mathrm{SpO}_{2}\right)$ of a patient fell below $90 \%$, the patient was provided with oxygen support. Aerobic exercises were performed for 30 minutes, including 15 minutes of treadmill exercises and 15 minutes of stationary bike exercises. All variables were evaluated at baseline (before PR [pre-PR]) and at the end of PR (post-PR).

\section{Statistical Analysis}

Data were analysed using IBM SPSS Statistics for Windows version 22.0 (IBM Corp., Armonk, NY, USA). Nominal variables were expressed as frequencies and percentages and were compared using cross tables. Continuous variables were expressed as mean, standard deviation (SD), median, and minimum and maximum values and normality of continuous variables were examined using the normality tests and graphical analyses in consideration of the sample size. Comparisons of the variables were performed through nonparametric tests. Mann-Whitney $U$ test was used for independent groups, and Wilcoxon signed rank test was used for repeated measurements. Kruskal-Wallis test was used for comparison of three groups. For all statistical comparisons, the level of significance was set at $\alpha=0.05$ (the probability of a type 1 error) and two-sided. A $p$ value of $<0.05$ was considered statistically significant. 


\section{RESULTS}

The study included 69 patients (55 males) with stable non-cystic bronchiectasis, and mean age of the patients was $62.6 \pm 9$ years. The general characteristics of the study patients are presented in Table 1 . The comparisons of the pre-PR and post-PR values of the study parameters in all patients (Table 2) revealed that the QoL and exercise capacity of the patients were improved with PR $(p<0.05)$.
According to BSI, 16 (23.2\%) patients (10 males) had mild bronchiectasis, $29(42.0 \%)$ patients (25 males) had moderate bronchiectasis, and 24 (34.8\%) patients (20 males) had severe bronchiectasis. Significant differences were found between the patients with mild, moderate, and severe bronchiectasis in terms of age, exercise capacity, and QoL at baseline $(p<0.05$ for all, Table 3).

Comparisons of the patients with mild, moderate, and severe bronchiectasis in terms of change $(\Delta)$

\section{Table 1. General characteristics of the study patients}

\begin{tabular}{lc} 
Variables & Patients with bronchiectasis $\mathbf{n = 6 9}$ \\
\hline Age, years & $62.6 \pm 9$ \\
Sex & $55(79.7)$ \\
$\quad$ Male & $14(20.3)$ \\
$\quad$ Female & $24.4 \pm 4.8$ \\
BMI, kg/m & $2.8 \pm 3.7$ \\
Number of EDVs in the previous year & $0.83 \pm 1.58$ \\
Number of hospitalizations in the previous year & $7.9 \pm 4.3$ \\
BSI & \\
\hline Data are presented as mean \pm standard deviation (SD) or number (percentage, \%), where appropriate. \\
SD: Standard deviation, BMI: Body mass index, EDVs: Emergency department visits, BSI: Bronchiectasis severity index.
\end{tabular}

\section{Table 2. Comparisons of pre-pulmonary rehabilitation and post-pulmonary rehabilitation values of the study parameters in} patients with bronchiectasis $(n=69)$

\begin{tabular}{|c|c|c|c|}
\hline Study parameters & Pre-PR Mean \pm SD & Post-PR Mean \pm SD & $\mathbf{p}$ \\
\hline $\mathrm{FEV}_{1}, \%$ & $46 \pm 20$ & $47 \pm 21$ & 0.126 \\
\hline $\mathrm{FEV}_{1} / \mathrm{FVC}, \%$ & $59 \pm 11$ & $59 \pm 12$ & 0.950 \\
\hline DLCO, \% & $36.9 \pm 21$ & $43 \pm 24$ & 0.087 \\
\hline $\mathrm{pH}$ & $7.39 \pm 0.03$ & $7.39 \pm 0.03$ & 0.289 \\
\hline $\mathrm{pCO}_{2}, \mathrm{mmHg}$ & $41.8 \pm 6.8$ & $42.3 \pm 7.8$ & 0.528 \\
\hline $\mathrm{SpO}_{2}, \mathrm{mmHg}$ & $93.2 \pm 5.7$ & $94.9 \pm 3.3$ & $<0.001$ \\
\hline $\mathrm{pO}_{2}, \mathrm{mmHg}$ & $72.1 \pm 14.7$ & $76.8 \pm 13.2$ & $<0.001$ \\
\hline $6 \mathrm{MWD}, \mathrm{m}$ & $334 \pm 123$ & $387 \pm 118$ & $<0.001$ \\
\hline SGRQ symptom score & $58.1 \pm 20$ & $51.7 \pm 19$ & 0.002 \\
\hline SGRQ activity score & $70.2 \pm 21$ & $60.5 \pm 23$ & $<0.001$ \\
\hline SGRQ impact score & 54.57 & 42.11 & $<0.001$ \\
\hline SGRQ total score & $60 \pm 19$ & $49.3 \pm 20$ & $<0.001$ \\
\hline HADS-anxiety score & $10.1 \pm 12$ & $6.1 \pm 3$ & $<0.001$ \\
\hline HADS-depression score & $8.5 \pm 12$ & $6.2 \pm 3$ & 0.020 \\
\hline MRC & $3.4 \pm 1.1$ & $2.4 \pm 1.2$ & $<0.001$ \\
\hline
\end{tabular}

PR: Pulmonary rehabilitation, FEV 1 : Forced expiratory volume, FVC: Forced vital capacity; DLCO: Diffusing capacity of the lungs for carbon monoxide (carbon monoxide transfer factor), $\mathrm{pCO}_{2}$ : Partial arterial carbon dioxide pressure, $\mathrm{SpO}_{2}$ : Peripheral arterial oxygen saturation, $\mathrm{pO} \mathrm{O}_{2}$ : Partial oxygen pressure, 6MWD: 6-minute walk distance, SGRQ: St. George's Respiratory Questionnaire, HADS: Hospital Anxiety and Depression Scale, MRC: Medical Research Council. 
Table 3. Comparison of the patients with mild, moderate and severe bronchiectasis in terms of study parameters assessed at baseline (pre-pulmonary rehabilitation)

\begin{tabular}{|c|c|c|c|c|}
\hline Parameters & $\begin{array}{c}\text { Patients with mild } \\
\text { bronchiectasis } \\
\mathbf{n}=\mathbf{1 0} \\
\text { Mean } \pm \text { SD } \\
\text { Min-Max }\end{array}$ & $\begin{array}{l}\text { Patients with moderate } \\
\text { bronchiectasis } \\
\mathbf{n}=29 \\
\text { Mean } \pm \text { SD } \\
\text { Min-Max }\end{array}$ & $\begin{array}{c}\text { Patients with severe } \\
\text { bronchiectasis } \\
\mathbf{n}=\mathbf{2 4} \\
\text { Mean } \pm \text { SD } \\
\text { Min-Max }\end{array}$ & $\mathbf{p}$ \\
\hline Age, years & $\begin{array}{l}56.8 \pm 8.6 \\
58(42-68)\end{array}$ & $\begin{array}{l}63.4 \pm 7.8 \\
65(38-74)\end{array}$ & $\begin{array}{l}65.5 \pm 9.3 \\
68(36-77)\end{array}$ & 0.007 \\
\hline $\mathrm{BMI}, \mathrm{kg} / \mathrm{m}^{2}$ & $\begin{array}{l}25.2 \pm 3.7 \\
25(21-34)\end{array}$ & $\begin{array}{l}25.2 \pm 5.3 \\
25(16-41)\end{array}$ & $\begin{array}{c}23 \pm 4.7 \\
24(15-31)\end{array}$ & 0.313 \\
\hline Number of EDVs in the previous year & $\begin{array}{c}0.4 \pm 0.6 \\
0\end{array}$ & $\begin{array}{c}1.5 \pm 1.8 \\
1(0-2)\end{array}$ & $\begin{array}{c}5.2 \pm 4.6 \\
4(0-15)\end{array}$ & $<0.001$ \\
\hline Number of hospitalizations in the previous year & $\begin{array}{l}0 \\
0\end{array}$ & $\begin{array}{c}0.1 \pm 0.3 \\
0\end{array}$ & $\begin{array}{l}1.9 \pm 2 \\
1(0-8)\end{array}$ & $<0.001$ \\
\hline $\mathrm{FEV}_{1}, \%$ & $\begin{array}{c}58 \pm 18 \\
58(27-82)\end{array}$ & $\begin{array}{c}48 \pm 21 \\
42(22-80)\end{array}$ & $\begin{array}{c}31 \pm 12 \\
31(18-61)\end{array}$ & $<0.001$ \\
\hline $\mathrm{FEV}_{1} / \mathrm{FVC}, \%$ & $\begin{array}{c}64 \pm 15 \\
66(34-80)\end{array}$ & $\begin{array}{c}60 \pm 13 \\
63(37-79)\end{array}$ & $\begin{array}{c}55 \pm 11 \\
54(34-75)\end{array}$ & 0.129 \\
\hline DLCO, \% & $\begin{array}{c}51 \pm 18 \\
53(26-70)\end{array}$ & $\begin{array}{c}33 \pm 17 \\
26(20-68)\end{array}$ & $\begin{array}{c}27 \pm 24 \\
20(11-54)\end{array}$ & 0.003 \\
\hline $\mathrm{pO}_{2}, \mathrm{mmHg}$ & $\begin{array}{c}79 \pm 17 \\
83(38-95)\end{array}$ & $\begin{array}{c}74 \pm 11 \\
74(46-93)\end{array}$ & $\begin{array}{c}64 \pm 13 \\
65(36-92)\end{array}$ & 0.001 \\
\hline $\mathrm{pCO}_{2}, \mathrm{mmHg}$ & $\begin{array}{c}38 \pm 4.6 \\
38(31-45)\end{array}$ & $\begin{array}{c}41 \pm 5.7 \\
41(32-57)\end{array}$ & $\begin{array}{c}44 \pm 8.2 \\
41(35-65)\end{array}$ & 0.077 \\
\hline $\mathrm{SpO}_{2}, \%$ & $\begin{array}{l}94.9 \pm 5.7 \\
96(75-98)\end{array}$ & $\begin{array}{l}94.3 \pm 3.7 \\
95(80-99)\end{array}$ & $\begin{array}{l}90.8 \pm 7.1 \\
93(70-98)\end{array}$ & 0.002 \\
\hline $\mathrm{pH}$ & $\begin{array}{c}7.39 \pm 0.04 \\
7.41(7.33-7.43)\end{array}$ & $\begin{array}{c}7.40 \pm 0.03 \\
7.40(7.35-7.45)\end{array}$ & $\begin{array}{c}7.39 \pm 0.04 \\
7.39(7.35-7.47)\end{array}$ & 0.962 \\
\hline $6 \mathrm{MWD}, \mathrm{m}$ & $\begin{array}{c}394 \pm 93 \\
417(200-520)\end{array}$ & $\begin{array}{c}358 \pm 114 \\
390(80-510)\end{array}$ & $\begin{array}{c}265 \pm 122 \\
290(40-460)\end{array}$ & 0.002 \\
\hline SGRQ symptom score & $\begin{array}{c}46.7 \pm 17.4 \\
45.4(26.4-76)\end{array}$ & $\begin{array}{c}55.7 \pm 21 \\
59.3(11.7-92)\end{array}$ & $\begin{array}{c}70.7 \pm 17.2 \\
73.3(33.4-95)\end{array}$ & 0.001 \\
\hline SGRQ activity score & $\begin{array}{c}59.2 \pm 17.6 \\
57(29-87)\end{array}$ & $\begin{array}{c}66.8 \pm 23 \\
66.3(29-100)\end{array}$ & $\begin{array}{c}84.1 \pm 16 \\
92.5(56-100)\end{array}$ & $<0.001$ \\
\hline SGRQ impact score & $\begin{array}{c}42.4 \pm 19.2 \\
44.6(12.8-76)\end{array}$ & $\begin{array}{l}51.3 \pm 20.8 \\
49(16-88.6)\end{array}$ & $\begin{array}{c}68.9 \pm 20.3 \\
67.4(34.8-99)\end{array}$ & 0.002 \\
\hline SGRQ total score & $\begin{array}{c}48.2 \pm 16 \\
47.4(22-75)\end{array}$ & $\begin{array}{c}57 \pm 18.8 \\
52.6(28-89)\end{array}$ & $\begin{array}{l}73.8 \pm 16.8 \\
77.2(47-96)\end{array}$ & $<0.001$ \\
\hline HADS-Anxiety score & $\begin{array}{l}8 \pm 4.5 \\
6(0-20)\end{array}$ & $\begin{array}{l}9.1 \pm 4.9 \\
8(0-20)\end{array}$ & $\begin{array}{l}10.1 \pm 4.9 \\
9.5(3-19)\end{array}$ & 0.065 \\
\hline HADS-Depression score & $\begin{array}{c}8.4 \pm 4.8 \\
6(1-20)\end{array}$ & $\begin{array}{l}7.4 \pm 4.3 \\
6.5(0-15)\end{array}$ & $\begin{array}{l}8 \pm 3.4 \\
8(2-15)\end{array}$ & 0.143 \\
\hline MRC dyspnoea scale score & $\begin{array}{l}2.3 \pm 0.8 \\
2.5(1-3)\end{array}$ & $\begin{array}{c}3.3 \pm 1.1 \\
3(1-5)\end{array}$ & $\begin{array}{c}4.1 \pm 0.9 \\
4(2-5)\end{array}$ & $<0.001$ \\
\hline \multicolumn{5}{|c|}{$\begin{array}{l}\text { SD: Standard deviation, Min-Max: Minimum-maximum, BMI: Body mass index, EDVs: Emergency department visits, FEV }{ }_{1} \text { : Forced expiratory volume, } \\
\text { FVC: Forced vital capacity, DLCO: Diffusing capacity of the lungs for carbon monoxide (carbon monoxide transfer factor), pCO } \text { partial arterial }_{\text {carbon }} \text { carbon dioxide pressure, SpO } \text { : Peripheral arterial oxygen saturation, pO2: Partial oxygen pressure, 6MWD: 6-minute walk distance, SGRQ: St. } \\
\text { George's Respiratory Questionnaire, HADS: Hospital Anxiety and Depression Scale, MRC: Medical Research Council. }\end{array}$} \\
\hline
\end{tabular}


between post-PR and pre-PR values of the study parameters $(\Delta=$ post-PR value - pre-PR value) revealed no significant differences between the patient groups in terms of exercise capacity and QoL ( $>0.05$ for all; Table 4).

\section{DISCUSSION}

In the present study, in which the efficacy of an 8 -week PR program was evaluated in patients with non-cystic bronchiectasis, it was found that the

Table 4. Comparison of the patients with mild, moderate and severe bronchiectasis in terms of the change ( $\Delta$ ) between the study parameters ( $\Delta=$ post-pulmonary rehabilitation value-pre-pulmonary rehabilitation value)

\begin{tabular}{|c|c|c|c|c|}
\hline Parameters & $\begin{array}{l}\text { Patients with mild } \\
\text { bronchiectasis } \\
\mathbf{n}=\mathbf{1 0} \\
\text { Mean } \pm \text { SD } \\
\text { Min-Max }\end{array}$ & $\begin{array}{l}\text { Patients with moderate } \\
\text { bronchiectasis } \\
\mathbf{n}=\mathbf{2 9} \\
\text { Mean } \pm \text { SD } \\
\text { Min-Max }\end{array}$ & $\begin{array}{c}\text { Patients with severe } \\
\text { bronchiectasis } \\
\mathbf{n}=\mathbf{2 4} \\
\text { Mean } \pm \text { SD } \\
\text { Min-Max }\end{array}$ & $\mathbf{p}$ \\
\hline$\Delta \mathrm{FEV}_{1}, \%$ & $\begin{array}{c}3.3 \pm 14.8 \\
0.5(-16-53)\end{array}$ & $\begin{array}{l}2.2 \pm 7.1 \\
1(-14-24)\end{array}$ & $\begin{array}{c}2 \pm 5.9 \\
0.5(-9-17)\end{array}$ & 0.928 \\
\hline$\Delta \mathrm{FEV}_{1} / \mathrm{FVC}, \%$ & $\begin{array}{c}3.9 \pm 11.7 \\
3.5(-18-29)\end{array}$ & $\begin{array}{l}1.3 \pm 11.6 \\
0(-18-31)\end{array}$ & $\begin{array}{l}-1.8 \pm 11.8 \\
-2(-26-31)\end{array}$ & 0.118 \\
\hline$\Delta \mathrm{DLCO}, \%$ & $\begin{array}{c}3.3 \pm 15.3 \\
-1.5(-12-36)\end{array}$ & $\begin{array}{l}8.2 \pm 16.5 \\
4(-20-67)\end{array}$ & $\begin{array}{l}-1.2 \pm 13.4 \\
-0.5(-32-21)\end{array}$ & 0.177 \\
\hline$\Delta \mathrm{pO}_{2}, \mathrm{mmHg}$ & $\begin{array}{l}7.2 \pm 13.8 \\
5(-11-39)\end{array}$ & $\begin{array}{c}4 \pm 8.3 \\
5(-23-16)\end{array}$ & $\begin{array}{c}4.9 \pm 10.1 \\
2.5(-13-29)\end{array}$ & 0.982 \\
\hline$\Delta \mathrm{pCO}_{2}, \mathrm{mmHg}$ & $\begin{array}{c}0.4 \pm 3.3 \\
0.4(-5.8-7)\end{array}$ & $\begin{array}{c}-0.5 \pm 4.5 \\
-0.4(-10-16)\end{array}$ & $\begin{array}{l}0.5 \pm 5.7 \\
2(-19-8)\end{array}$ & 0.126 \\
\hline$\Delta \mathrm{SpO}_{2}, \mathrm{mmHg}$ & $\begin{array}{c}1.2 \pm 5.2 \\
0.4(-3.7-19)\end{array}$ & $\begin{array}{c}1 \pm 1.8 \\
0.6(-1.8-5)\end{array}$ & $\begin{array}{c}2.8 \pm 6.1 \\
1.8(-6.5-25)\end{array}$ & 0.176 \\
\hline$\Delta \mathrm{pH}$ & $\begin{array}{c}-0.01 \pm 0.03 \\
-0.01(-0.09-0.04)\end{array}$ & $\begin{array}{c}-0.01 \pm 0.04 \\
0(-0.14-0.06)\end{array}$ & $\begin{array}{c}0 \pm 0.03 \\
0.01(0.07-0.04)\end{array}$ & 0.694 \\
\hline$\triangle 6 \mathrm{MWD}, \mathrm{m}$ & $\begin{array}{c}49 \pm 38 \\
40(0-140)\end{array}$ & $\begin{array}{c}48 \pm 90 \\
50(-320-200)\end{array}$ & $\begin{array}{c}60 \pm 59 \\
42(-40-170)\end{array}$ & 0.926 \\
\hline$\triangle$ SGRQ symptom score & $\begin{array}{l}-5.5 \pm 15.5 \\
-5.3(-32-26)\end{array}$ & $\begin{array}{l}-1.4 \pm 15.4 \\
-1.2(-28-29)\end{array}$ & $\begin{array}{c}-14.3 \pm 15 \\
-12.4(-51-6)\end{array}$ & 0.028 \\
\hline$\triangle$ SGRQ activity score & $\begin{array}{l}-14.5 \pm 18.5 \\
-12.3(-54-11)\end{array}$ & $\begin{array}{c}-4.3 \pm 21.7 \\
-5.9(-67-64)\end{array}$ & $\begin{array}{l}-13.8 \pm 19.1 \\
-6.7(-48-12)\end{array}$ & 0.243 \\
\hline$\triangle S G R Q$ impact score & $\begin{array}{l}-13.8 \pm 20.1 \\
-12.4(-49-5)\end{array}$ & $\begin{array}{c}-8.2 \pm 19.2 \\
-10.2(-45-42)\end{array}$ & $\begin{array}{c}-17.5 \pm 15.6 \\
-12.2(-54-2.5)\end{array}$ & 0.344 \\
\hline$\triangle \mathrm{SGRQ}$ total score & $\begin{array}{l}-12.7 \pm 15 \\
-13(-42-8.6)\end{array}$ & $\begin{array}{c}-6 \pm 15.1 \\
-5.4(-34-46)\end{array}$ & $\begin{array}{c}-15.9 \pm 14 \\
-10.9(-49--0.6)\end{array}$ & 0.075 \\
\hline$\Delta$ HADS-Anxiety score & $\begin{array}{l}-8.7 \pm 25 \\
-3(-99-2)\end{array}$ & $\begin{array}{l}-2.7 \pm 3.5 \\
-2(-10-2)\end{array}$ & $\begin{array}{l}-2 \pm 3.9 \\
-1(-14-2)\end{array}$ & 0.507 \\
\hline$\triangle$ HADS- Depression score & $\begin{array}{l}-7.2 \pm 24.7 \\
-2(-96-4)\end{array}$ & $\begin{array}{c}-1 \pm 3.1 \\
-0.5(-10-6)\end{array}$ & $\begin{array}{c}-0.6 \pm 3.1 \\
0(-5-4)\end{array}$ & 0.745 \\
\hline$\Delta \mathrm{MRC}$ dyspnoea scale score & $\begin{array}{l}-0.88 \pm 1 \\
-1(-3-1) \\
\end{array}$ & $\begin{array}{c}-1.1 \pm 1.2 \\
-1(-4-2)\end{array}$ & $\begin{array}{c}-0.8 \pm 1.1 \\
-1(-4-1) \\
\end{array}$ & 0.320 \\
\hline \multicolumn{5}{|c|}{$\begin{array}{l}\text { SD: Standard deviation, Min-Max: Minimum-maximum, BMI: Body mass index, EDVs: Emergency department visits, FEV }{ }_{1} \text { : Forced expiratory volume, } \\
\text { FVC: Forced vital capacity, DLCO: Diffusing capacity of the lungs for carbon monoxide (carbon monoxide transfer factor), pCO }{ }_{2} \text { : Partial arterial carbon } \\
\text { dioxide pressure, SpO } \mathrm{Sp}_{2} \text { : Peripheral arterial oxygen saturation, pO2: Partial oxygen pressure, 6MWD: 6-minute walk distance, SGRQ: St. George's } \\
\text { Respiratory Questionnaire, HADS: Hospital Anxiety and Depression Scale, MRC: Medical Research Council. }\end{array}$} \\
\hline
\end{tabular}


patients with bronchiectasis had improved levels of QoL and exercise capacity after the PR program and that the patients grouped into 3 according to their disease severity (mild, moderate and severe) using the BSI had similar levels of improvement.

In a previous study by Zanini et al. (11) conducted on 108 bronchiectasis patients, an average change of 35 $\mathrm{m}$ in 6MWD and a significant improvement in QoL [EuroQol visual analogue scale (EQ-VAS)] have been observed after PR (11). In the study, 55\% of the patients were females and mean age was 71 years (11). In the present study, $20.3 \%$ of our patients were females and mean age was 62.6 years, and a significant improvement was observed in both QoL and $6 \mathrm{MWD}$. Both the present study and the study by Zanini et al. (11). included patients with and without airflow obstruction.

In a retrospective study by Ong et al. (12) in which 95 bronchiectasis patients (mean age, 67 years; 53\% females) underwent PR, significant improvements have been reported in the results of the Chronic Respiratory Disease Questionnaire (CRQ) and in the 6MWD after PR. In addition, they have compared bronchiectasis patients with a matched chronic obstructive disease (COPD) patient group who completed the same PR program and reported no significant difference between the groups (12). In the present study, the QoL of the patients was assessed using the SGRQ and a significant improvement was detected in the post-PR results as compared with the pre-PR results for all domains of the SGRQ in the whole study group. Similarly, a significant improvement was also observed in the 6MWD of the whole study group after the 8-week PR program.

In a randomized controlled trial (RCT), 30 patients with non-cystic fibrosis bronchiectasis have been randomized either to receive acapella (control group) or to receive PR (intervention group) in addition to acapella for an 8-week period (13). Accordingly, a significant change in the QoL (SGRQ) and exercise capacity (incremental shuttle walk test [ISWT] and endurance walk test [EWT]) has been reported in the intervention group, whereas no change was reported in the control group. Mean ages of the study groups were similar (64.6 years vs. 64.8 years), and baseline evaluation was worse for the control group in terms of exercise capacity (ISWT: $343 \mathrm{~m}$ in the control group and $287 \mathrm{~m}$ in the intervention group). The patients in the intervention group have been reported to have significantly improved results despite their lower exercise capacities (13). In the present study, in which the mean age of the patients was similar to those reported in the mentioned RCT, three patient groups were formed based on disease severity, and the differences between the groups in terms of improvements were not found to be significant after the PR program.

Patients with bronchiectasis frequently experience acute exacerbations (14). Since frequent airway infection and inflammation cause airway damage resulting in further infection and thereby airway and lung parenchyma destruction, (15) those are independent predictors of progressive decline in respiratory function (16) and indicators of poor prognosis (17). In an RCT investigating short and long term effects of exercise training in non-cystic fibrosis bronchiectasis, exercise training has been observed to increase the incremental shuttle walk distance (ISWT) and the $6 \mathrm{MWD}$; however, it has been reported that such improvements were not sustained at the $6^{\text {th }}$ and $12^{\text {th }}$ months (18). Nevertheless, fewer exacerbations have been reported in the PR group over 12 months follow-up, with longer time to the first exacerbation (8 months in the PR group and 6 months in the control group, $p=0.047$ ) (18). In the present study, the patients with bronchiectasis were observed to have improved QoL and 6MWD with the 8-week PR program; however, the effects of PR on the frequency of exacerbations in patients with bronchiectasis were not investigated in this study.

In a systematic review including 4 recent RCTs evaluating PR or exercise training as compared with no treatment in patients with bronchiectasis, it has been reported that supervised outpatient programs in stable patients provided short-term benefits in endurance and functional exercise capacity, cough-related symptoms, and disease-specific health-related QoL with reductions in dyspnoea and fatigue levels but that improvements were not sustained beyond 3 months (19).

Unlike COPD patients, although patients with bronchiectasis are not referred for PR, they could also benefit from PR. Exercise programs improve physical fitness levels of patients with cystic fibrosis and non-cystic fibrosis bronchiectasis (20). According to the newest guidelines, PR is strongly recommended 
based on high quality of evidence suggesting that patients with bronchiectasis and impaired exercise capacity should participate in a PR programme and perform regular exercise. All interventions should be arranged according to the patient's symptoms, physical capability, and disease characteristics (1).

In a study conducted by Ong et al. (12), it has been reported that the patients with bronchiectasis had improved exercise capacity and health-related QoL (assessed by the CRQ) following a 6- to 8-week out-patient PR program and that these improvements were also sustained for up to 12 months after PR. The study by Ong et al. (12) differs from other studies in the literature $(18,19)$. in terms of the long-term effects of PR. In the present study, the QoL of the patients were evaluated using the SGRQ; although the observed benefits of PR were similar to those found in other studies, the long-term effects of PR were not evaluated in the present study. In a recently published meta-analysis, patients with impaired exercise capacity have been strongly recommended to participate in PR and take regular exercise based on high quality of evidence (4). In the present study, the patients with severe bronchiectasis were older, had lower exercise capacity, had more frequent daily symptoms, and had lower $\mathrm{FEV}_{1} \%, \mathrm{DLCO} \%$, and $\mathrm{SpO} 2$ values as compared with the patients with mild and moderate disease severity. However, it was observed that patients with mild, moderate, and severe bronchiectasis were all benefited equally from the PR program regardless of their disease severity. To the best of our knowledge, this study is the first to investigate the effects of PR program in bronchiectasis patients based on disease severity.

\section{Limitations}

Some patients in the present study had airflow limitations. PR has been proven to provide benefits in chronic respiratory diseases. In the present study, the patients benefited from PR and the airflow limitation may have contributed to this benefit. As the assessment of disease severity is relatively a new concept in bronchiectasis, it will be debatable if disease severity alone is sufficient to guide clinical care in bronchiectasis patients. Having not measured endurance time was also a limitation.

\section{CONCLUSION}

In the present study, PR program was shown to increase exercise capacity and QoL in patients with bronchiectasis. No difference was determined in the efficacy of PR between the patients with different disease severity (mild, moderate, severe) determined by the BSI. Appropriate patients with bronchiectasis should be referred to PR programs regardless of their disease severity. Although some patients had airway limitations, the benefits of PR cannot be attributed to the COPD component alone as each patient was benefited from the PR program. It was concluded that PR could be beneficial for bronchiectasis, which is a chronic airway disease.

Ethical Committee Approval: The study was approved by the Ethics Committee of Suat Seren Chest Diseases and Thoracic Surgery Research and Training Hospital (Approval number: (16-03-2016-2906), Date: 15.03.2016). All procedures performed in studies involving human participants were in accordance with the ethics standards of the institutional and/or national research committee and with the 1964 Helsinki declaration and its later amendments or comparable ethical standards.

\section{CONFLICT of INTEREST}

The authors declare that they have no conflict of interest.

\section{AUTHORSHIP CONTRIBUTIONS}

Concept/Design: SD, HŞ

Analysis/Interpretation: All of authors

Data acqusition: HŞ

Writing: All of authors

Clinical Revision: All of authors

Final Approval: All of authors

\section{REFERENCES}

1. Polverino E, Goeminne PC, McDonnell MJ, Aliberti S, Marshall SE, Loebinger MR, et al. European Respiratory Society guidelines for the management of adult bronchiectasis. Eur Respir J 2017; 50 (3): 1700629.

2. Chalmers JD, Aliberti S, Polverino E, Vendrell M, Crichton $M$, Loebinger M, et al. The EMBARC European Bronchiectasis Registry: protocol for an international observational study. ERJ Open Res 2016; 2 (1): 00081-2015.

3. Chalmers JD, Goeminne P, Aliberti S, McDonnell MI, Lonni $S$, Davidson J, et al. The bronchiectasis severity index. An international derivation and validation study. Am J Respir Crit Care Med 2014; 189(5): 576-85.

4. Chalmers JD, Chotirmall SH. Bronchiectasis: new therapies and new perspectives. Lancet Respir Med 2018; 6(9): 715-26. 
5. Lee AL, Button BM, Ellis $S$, Stirling $R$, Wilson JW, Holland $A E$, et al. Clinical determinants of the 6-Minute Walk Test in bronchiectasis. Respir Med 2009; 103(5): 780-5.

6. Spruit MA, Singh SJ, Garvey C, ZuWallack R, Nici L, Rochester C, et al; ATS/ERS Task Force on Pulmonary Rehabilitation. An official American Thoracic Society/ European Respiratory Society statement: key concepts and advances in pulmonary rehabilitation. Am / Respir Crit Care Med 2013; 188(8): e13-64. Erratum in: Am J Respir Crit Care Med 2014; 189 (12): 1570.

7. ATS Committee on Proficiency Standards for Clinical Pulmonary Function Laboratories. ATS statement: guidelines for the six-minute walk test. Am J Respir Crit Care Med 2002; 166(1): 111-7.

8. Polatı M, Yorgancıoğlu A, Aydemir Ö, Demirci NY, Kırkıl $G$, Naycı SA, et al. St. George solunum anketinin Türkçe geçerlilik ve güvenilirliği [Validity and reliability of Turkish version of St. George's respiratory questionnaire]. Tuberk Toraks 2013; 61(2): 81-7.

9. Zigmond AS, Snaith RP. The hospital anxiety and depression scale. Acta Psychiatr Scand 1983; 67(6): 361-70.

10. Aydemir O, Guvenir T, Küey L, Kültür S. Validity and reliability of Turkish version of Hospital Anxiety and Depression Scale. Turk Psikiyatri Derg 1997: 8: 280-8. [Turkish].

11. Zanini A, Aiello M, Adamo D, Cherubino F, Zampogna E, Sotgiu G, et al. Effects of Pulmonary Rehabilitation in Patients with Non-Cystic Fibrosis Bronchiectasis: A Retrospective Analysis of Clinical and Functional Predictors of Efficacy. Respiration 2015; 89(6): 525-33.

12. Ong HK, Lee AL, Hill CJ, Holland AE, Denehy L. Effects of pulmonary rehabilitation in bronchiectasis: A retrospective study. Chron Respir Dis 2011; 8(1): 21-30.
13. Mandal P, Sidhu MK, Kope L, Pollock W, Stevenson LM, Pentland $L$, et al. A pilot study of pulmonary rehabilitation and chest physiotherapy versus chest physiotherapy alone in bronchiectasis. Respir Med 2012; 106(12): 1647-54.

14. Chang $A B$, Bilton D. Exacerbations in cystic fibrosis: Noncystic fibrosis bronchiectasis. Thorax. 2008; 63(3): 26976.

15. Morrissey BM. Pathogenesis of bronchiectasis. Clin Chest Med 2007; 28(2): 289-96.

16. Finklea JD, Khan G, Thomas S, Song J, Myers D, Arroliga AC. Predictors of mortality in hospitalized patients with acute exacerbation of bronchiectasis. Respir Med 2010 104(6): 816-21.

17. Martínez-García MA, Soler-Cataluña JJ, Perpiñá-Tordera M, Román-Sánchez P, Soriano J. Factors associated with lung function decline in adult patients with stable non-cystic fibrosis bronchiectasis. Chest 2007; 132(5): 1565-72.

18. Lee AL, Hill Cl, Cecins N, Jenkins S, McDonald CF, Burge $A T$, et al. The short and long term effects of exercise training in non-cystic fibrosis bronchiectasis--a randomised controlled trial. Respir Res 2014; 15(1): 44.

19. Lee AL, Hill CJ, McDonald CF, Holland AE. Pulmonary rehabilitation in individuals with non-cystic fibrosis bronchiectasis: A systematic review. Arch Phys Med Rehabil 2017; 98(4): 774-82.e1.

20. Burtin C, Hebestreit $H$. Rehabilitation in patients with chronic respiratory disease other than chronic obstructive pulmonary disease: exercise and physical activity interventions in cystic fibrosis and non-cystic fibrosis bronchiectasis. Respiration 2015; 89(3): 181-9. 